\title{
Protective excise taxation
}

\author{
Michele Santoni \\ (Università degli Studi di Milano) \\ Forthcoming in the Journal of Industry, Competition and Trade, 2017.
}

\begin{abstract}
In a small open economy composed of unionised international Cournot-Nash duopolies, a self-interested government has unilateral incentives to set higher specific domestic excise duties under the destination principle when the typical foreign firm is dominant and the import-competing sector is small. Excise taxes may emerge in political equilibrium when domestic firms and unions lobby for protection and the government is unable to use alternative protective policies because of international agreements. In so far as the government is prepared to exchange tax revenues for political contributions, under some conditions the excise tax rate will be higher than the one chosen without lobbying.
\end{abstract}

Keywords: Excise taxation, Protectionism, Unionised International Oligopoly, Lobbying

JEL Codes: D43, D72, F16, H22, J51

\section{Michele Santoni \\ DEMM \\ Università degli Studi di Milano \\ 20122 Milano (MI) \\ ITALY \\ Tel. +39-0250321511 \\ Email : Michele.Santoni@unimi.it}

*I would like to thank a referee of this Journal for useful comments. I am responsible for any mistake. 


\section{Introduction}

Excise taxes are often imposed in imperfectly competitive product markets (for example, alcoholic and nonalcoholic beverages, tobacco products, oil products and vehicles) in which home and foreign firms compete for domestic consumers. In such a situation, a domestic government can use specific consumption taxes under the destination principle (meaning that taxes are paid where the good is consumed) not only for raising revenue, but also for favouring domestic over foreign producers, especially in industries with dominant foreign firms. This strategic motive for excise taxation is likely to have become more important over the years, given that discriminatory trade and industrial policies are becoming harder or impossible to implement in the face of international trade agreements and anti-trust legislation. Moreover, as long as these policies are effective, domestic producers have potential incentives to lobby the government for protection by means of excise taxation.

There is a lot of anecdotal evidence on the potential use of excise taxation as a protectionist device. For example, articles 95-97 of the European Community treaty prohibit a Member State from using internal taxes to discriminate between imports from other Member States and similar domestic goods. However, between 1957 and 1999 the European Commission brought before the European Court of Justice (ECJ) more than one hundred cases regarding national tax laws that were alleged to be discriminatory. For excise taxation to be considered protective by the ECJ, however, it is not sufficient that tax rates differ across similar goods. For example, in 2001 the EU Commission raised the issue of the protective use of excise taxation by Sweden. The EU was concerned for the higher excise tax rate imposed on wine, which is mainly imported, compared to beer, which is mainly domestically produced. ${ }^{1}$ Sweden did not amend its tax law and in 2004 the Commission took it to court. In 2008, however, the ECJ ruled that the "different tax treatment of beer and wine in Sweden did not infringe Community law". The ECJ pointed out that "the price difference between the two products is virtually the same before taxation as after it (a liter of wine of $12.5 \%$ vol. costing just over twice the price of a liter of beer). In that context, the Court finds that the Commission has not shown

\footnotetext{
1 "The EU cannot tolerate protectionism within the Internal Market whatever form it takes. Imposing higher taxes on wine, that comes from other Member States, compared to beer, mainly produced in Sweden, may be a more subtle way to defend domestic production than import quotas or tariffs, but the effect is the same-illegal protection.", Mr. Frits Bolkestein (EU Taxation commissioner in 2001).
} 
that the difference between the price of strong beer and the price of wine in competition with that beer is so slight that the difference in the excise duty applicable to those products in Sweden is likely to influence consumer behavior" (Europa Press Release n.23/08). However, high excise tax rates on wine could qualify as a "profitable cost increase" of the kind considered by Seade (1985) and Février and Linnemer (2004) among others. In this case, they could have benefitted fringe Swedish wine producers (meeting less than $1 \%$ of domestic demand in 2009), thus achieving effective protection in the wine industry.

This paper will address the issue of protective excise taxation by presenting a model of a small open economy with an import-competing Cournot-Nash sector and a competitive export sector. The paper will show that, under some conditions, excise taxation in the import-competing sector may favour fringe domestic producers over dominant foreign producers. In such a situation, excise taxation may emerge endogenously in political-economy equilibrium with lobbying. More specifically, by assuming unit-elastic product demand curves, domestic union wage bargaining and a self-interested government, the paper derives the following main results. Firstly, provided that the typical domestic firm is sufficiently smaller-thus inefficient- than the typical foreign firm, a marginal increase in the excise duty lowers imports and raises domestic workers' utility and home firms' profits at the industry level (Proposition 1). This result implies that, depending on the initial foreign market share, taxes become a profitable instrument for protection, potentially inducing domestic producers to lobby for taxation. Second, when these conditions occur, the revenue-maximising tax rate is an increasing function of the degree of foreign penetration (Proposition 2). Finally, as long as the selfinterested government is prepared to trade off tax revenue and political contributions, under some conditions industrial lobbying by firms and unions leads the government to set a higher tax rate than without lobbying, other things being equal (Proposition 3).

The paper is organised as follows. Section 2 presents an overview of the related literature and of the main assumptions of this paper. Section 3 outlines a model of a two-sector small open economy in which the excise tax may become a protectionist device for the net import sector. Section 4 analyses the optimal tax rate a rational Leviathan government would choose had no lobbies existed. Section 5 considers the excise tax rate in equilibrium with lobbying by domestic producers. Section 6 discusses the model's main assumptions. Section 7 concludes. 


\section{Related literature}

This paper is related to three strands of the literature. Firstly, several papers have studied how a common shock to marginal costs affects firms' profits and social welfare in an asymmetric Cournot oligopoly with fixed number of firms (for example: Seade, 1985, Kimmel, 1992, Anderson et al., 2001, Février and Linnemer, 2004, Reny at al., 2012, Amir et al., 2016, Häckner and Herznig, 2016). A result of this literature is that such a shock can be profitable for high-cost firms vis-à-vis low-cost firms. The intuition is that the uniform cost increase penalizes the more efficient firms by lowering their cost differentials relatively to the less efficient firms, which allows the latter to steal market shares. Conditional on the presence of a sufficient degree of cost over-shifting (that occurs when the pass-through of cost increases to the consumer gross price is greater than $100 \%$ ), the shock may result in higher profits for the high-cost firms and lower profits for the low-cost firms. In turn, these effects have been shown to depend on market conditions, including the curvature of demand, the number of active firms and their initial market shares (Weyl and Fabinger, 2013: 552-560, provide a general analysis with imperfectly competitive product markets). These papers typically consider a single domestic industry, assume exogenous marginal costs and focus on the partial equilibrium effects of the cost shock.

In the current paper, the basic mechanism for a profitable cost increase is embedded in a small-open economy framework, which opens up the possibility of domestic taxation operating as an effective rentshifting device when total production by home firms is much smaller than domestic demand (see below). Moreover, the paper assumes that domestic marginal costs are determined at the firm level in a Nash negotiation between firms and unions. This implies that they will react endogenously to changes in the excise tax rate. Although the assumption on the curvature of demand is sufficient for generating profit over-shifting (namely, profits increasing with marginal costs) in the presence of cost asymmetries, domestic unions will influence both the degree of cost pass-through and the extent of rent shifting at the industry level from (the more efficient) foreign firms towards (the less efficient) domestic firms (see below). By considering a twosector economy, the paper will be able as well to trace out the general equilibrium effects of the tax change on the consumer price index (CPI) and national income. Considering these effects, the paper will show when a cost increase that a typical domestic producer perceives as being profitable (namely, for given CPI and 
national income) will actually raise domestic rents in general equilibrium, thus providing producers to lobbying for excise taxation at the industry level (see below).

Second, although anecdotal evidence suggests that many governments make use of discriminatory domestic taxation, the public finance literature analysing this issue overlooks the possibility of profitable tax increases for home producers. In two-country models of international Cournot duopolies (for example, Kay and Keen, 1987, Keen and Lahiri, 1993, Lahiri and Ono, 1997, Keen et al., 2002, Keen and Ligarth, 2005), this possibility is ruled out by assuming a linear product demand curve. In these papers, the rationale for having a positive domestic excise duty rate is instead related to a terms of trade effect: whenever the country is a net importer of the good, a benevolent government has the incentive to reduce domestic consumption in order to lower the world price of the imported good. For this reason, the smaller is the home firm's market share, the higher is the optimal tax rate in a non-cooperative Nash equilibrium with the foreign government (Keen et al., 2002: 1563-64). Considering a domestic market, Brander and Spencer (1984, Propositions 1 and 2) show that rent-extraction motivations may induce a benevolent domestic government to set a positive or a negative specific tariff/tax, conditional on the curvature of demand and the initial foreign firm's market share. For example, with a monopolistic foreign firm and a linear demand curve, it is optimal to introduce a specific tax (Katrak, 1977), whereas a subsidy is optimal if demand has constant elasticity. In a Cournot duopoly between a home and a foreign firm, the government can find it optimal to introduce a tariff if the curvature of demand is not too convex. Collie (2006) extends this analysis by considering both ad valorem and specific tariffs and subsidies. He shows that the welfare properties of alternative instruments are related to their "rationalization effects", namely their effects on the equilibrium size of domestic and foreign firms, which depend on initial cost asymmetries and the curvature of demand. However, as long as outputs of all firms are assumed to be strategic substitutes, this rules out the range of convex demands thereby a profitable cost increase à la Seade (1985) is a possibility.

The current paper assumes that the government is a self-interested agent. The government raises revenue, which it uses for its own purposes, from both the excise tax and the political contributions that lobbies are prepared to pay in exchange for protective taxation. With no producers' lobbying, the government chooses the excise tax rate in order to maximise the CPI-indexed excise tax revenue in the import sector, taking as 
well into account the effects of the tax on national income. If import sector producers are able to form lobbies, the self-interested government chooses the tax rate as if maximising the sum of tax revenues and import-sector producer surplus, thus trading off tax revenue and political contributions (see section 5 below). In either case, the government disregards domestic consumer surplus completely. A possible rationale for this assumption is that consumption of the excisable good is potentially associated with negative externalities or permanent negative effects on individuals' health (Bonnet and Réquillart, 2013). As long as society (or a majority of voters) deems it worthy to discouraging (excessive) consumption of the excisable good, and provided the optimal Pigouvian tax cannot be computed exactly, the government will legitimately set its excise tax policy independently of its effects on consumer surplus. This assumption seems reasonable for goods such as alcohol, tobacco or soda drinks. It is also consistent with the view taken by policy-oriented economists (Acheson, 1977: 248; Bird and Wallace, 2010). ${ }^{2}$

Finally, there is a literature studying how lobbying affects government policies when: i) labour markets are unionised (Rama and Tabellini, 1998, Palokangas, 2003, Matschke and Sherlund, 2006, Matschke, 2010); ii) Leviathan governments levy an excise tax (Esteller-Moré et al., 2012). This paper follows Palokangas' (2003) version of Grossman and Helpman's (2002, chapter 4) protection-for-sale model. However, whereas Palokangas (2003) considers firms and unions lobbying a quasi-benevolent government that chooses both profit and wage taxation and labour market regulation, this paper assumes that the self-interested government takes labour market imperfections as given. Matschke and Sherlund (2006) also incorporate collective bargaining into the protection-for-sale model by assuming that tariffs are the only government instrument. In their paper wage-bill maximising unions are organised at the industry level and bargain with competitive firms over both wages and employment. Firms employ non-union workers at the union wage as well. Their results suggest that a quasi-benevolent government will choose a lower equilibrium tariff than in Grossman and Helpman (2002), who assume competitive labour markets and fixed wages. The basic mechanism at

\footnotetext{
2 “...An important argument that makes taxing alcohol attractive to policy makers is that it is often relatively easy to sell such taxes to the public owing the negative image (and reality) associated with alcohol consumption. We are not able to measure the external costs of excessive alcohol consumption very well in most countries. Nonetheless, people seem to accept that such costs exist and justify especially heavy taxation of alcohol.... How much (and how) alcohol is taxed in any country appears more to reflect history, revenue needs, and protectionism than either economic analysis or social policy.", Bird and Wallace (2007: 7, 11).
} 
work is a wage externality: provided union coverage is complete, protection is a public good for workers, as long as it increases industrial wages. However, only union workers contribute to lobby activities and this leads to a lower tariff. These models predict larger tariffs in sectors with lower import penetration. As regards Esteller-Moré et al. (2012), their view of the government as a tax revenue maximizing Leviathan that is "ready to give up part of their tax revenues in exchange of monetary transfers" (Ivi: 297) from lobbies is similar to the one taken here. However, they consider a model with symmetric domestic Cournot firms facing a linear product demand curve. Therefore, profits are decreasing in the tax rate and producers lobby for tax rates cuts. Lobbying for high taxes is only undertaken by organizations willing to reduce as much as possible consumption externalities, which they model explicitly, associated with the excisable good.

This paper will instead show that, if foreign firms are largely dominant, with a unit-elastic industry demand the higher is import penetration, the higher is the excise tax rate set by a Leviathan and the higher is the incentive for domestic producer to lobby for tax hikes that increase their rents, other thing being equal.

\section{The model}

The model of the economy builds on Santoni (1996), while lobbying activity is modelled as in Palokangas (2003). The home country is a small open economy composed of two sectors: a competitive net export sector, producing the numéraire good that is traded internationally, and a Cournot-Nash net import sector. The country is able to affect its terms of trade, as long as it exercises some degree of market power in the Cournot good it produces, although it smallness means that it treats foreign variables (such as foreign prices, income and number of firms) as given (Dixit 1987). The net import sector is composed of a fixed and large number of identical $\mathrm{j}=1$...f duopolies. Each duopoly produces a homogeneous good that is sold to domestic consumers only. Each duopoly is composed of a unionised home firm and a non-unionised foreign firm. This market structure may be justified by a combination of fixed entry costs (larger for foreign versus domestic firms) and variable production costs (lower for foreign versus domestic firms). The presence of many identical industries in the import sector is a useful simplifying modelling device in the spirit of Neary (2010)'s "large in the small but small in the large" general oligopolistic equilibrium approach. It is used for

justifying the assumption of aggregate price taking by part of each single unionised oligopoly. To be sure, 
with many industries, the typical home firm-union bargaining unit perceives no effects of changes in its own industrial price level on the general price index. Thus, the latter is treated as given when the home firm-union pair chooses industry wages.

Domestic households are allocated ex ante and symmetrically to a sector and then to an industry. They offer one unit of labour with fixed disutility $0<\theta<1$, such that their participation decision condition is $\mathrm{w} / \mathrm{P} \geq \theta$, where $\mathrm{w}$ is the wage rate and $\mathrm{P}$ is the consumer price level. Labour is the only input and labour markets are segmented. Thus, labour is immobile between sectors and countries.

The level of economic activity is demand-determined. This implies that the domestic reservation wage is equal to $\theta \mathrm{P}$, corresponding to a constant $\mathrm{CPI}$-indexed wage equal to $\theta$. Thus, the net import sector and the economy have underemployment (à la Calmfors, 1982) or union-voluntary unemployment in equilibrium: some workers in the union sector will not find a job at the prevailing union wage. ${ }^{3}$

Households have identical Cobb-Douglas preferences over goods, $U=\left(c^{\mathrm{E}}\right)^{1-\beta}\left(c^{\mathrm{I}}\right)^{\beta}$, yielding aggregate demands of the form $c^{E}=(1-\beta) \Omega, c^{\mathrm{I}}=\beta \Omega / \mathrm{p}^{\mathrm{I}}$, where $\mathrm{c}^{\mathrm{E}}$ and $\mathrm{c}^{\mathrm{I}}$ denote consumption in the export and import sectors, respectively. $0<\beta<1$ is the relative size of the import sector; $\mathrm{p}^{\mathrm{I}}$ is the relative price of imports (a rise in $\mathrm{p}^{\mathrm{I}}$ deteriorates the terms of trade). These assumptions imply that the general price level corresponds to the true cost-of-living index: $\mathrm{P}=\left(\mathrm{p}^{\mathrm{I}}\right)^{\beta}$. $\Omega$ is the total income received (the sum of domestic profits and labour income in both sectors). The government is self-interested and aims at maximising its rents by imposing a specific excise tax and by collecting political contributions from lobbies in the import sector. Tax revenue and political contributions do not enter the household aggregate income, given that the government uses them for its own consumption. Provided aggregate demand is symmetrically distributed across industries, the inverse demand function in the typical jth duopoly is unit-elastic: $\mathrm{p}_{\mathrm{J}}^{\mathrm{I}}=\psi / \mathrm{c}_{\mathrm{J}}^{\mathrm{I}}$, where $\psi=\{\beta \Omega / \mathrm{f}\}$ is the average expenditure in the import sector and $f$ is the fixed number of duopolies.

Turning to the supply side of the economy, in the competitive numéraire export sector the representative firm produces a homogeneous good by using a decreasing returns to labour technology,

\footnotetext{
${ }^{3}$ Allowing for labour mobility between union (net imports) and non-union (net exports) sectors would imply that the non-union wage is determined by the equality between labour demand in the export sector and the residual labour supply (total fixed labour supply minus employment in the import sector). This full-employment regime is not considered here.
} 
$\mathrm{X}^{\mathrm{E}}=\left(\mathrm{N}^{\mathrm{E}}\right)^{\alpha}$, with $0<\alpha<1$. Profit maximisation yields the optimal output supply $\mathrm{X}^{\mathrm{E}}=\left[\alpha / \mathrm{w}^{\mathrm{E}}\right]^{\alpha /(1-\alpha)}$. The export sector wage is equal to $\mathrm{w}^{\mathrm{E}}=\theta \mathrm{P}$, as long as the full employment constraint does not bind. In the imperfectly competitive import sector, the sequence of events is as follows. Firstly, domestic unions and firms lobby the government on its tax policy by announcing contributions. Second, the government sets the tax rate and collects the contributions. Third, there is wage bargaining at the firm level between the typical home firm and its union, while the foreign wage rate is taken as exogenous. Finally, home and foreign firms compete in output/employment levels à la Cournot-Nash.

\subsection{Tax incidence in the typical Cournot-Nash industry of the import sector}

The sectoral equilibrium solution is obtained by backward induction. In the output game, the typical $\mathrm{j}^{\text {th }}$ duopoly produces the identical and homogeneous good $\mathrm{X}_{\mathrm{j}}$ using a linear-in-labour technology. ${ }^{4}$ The number of firms is fixed and entry costs are sunk at this stage. For given government's tax policy and wage rates, firms maximise profits, $\Pi^{\mathrm{h}}=\mathrm{X}^{\mathrm{h}}\left[\mathrm{p}-\left(\mathrm{w}^{\mathrm{h}}+\mathrm{s}\right)\right]$ and $\Pi^{*}=\mathrm{X}^{*}\left[\mathrm{p}^{\mathrm{I}}-\left(\mathrm{w}^{*}+\mathrm{s}\right)\right]$ by simultaneous and independent choice of outputs $\mathrm{X} ; \mathrm{s}$ is the specific excise tax rate, and $\mathrm{w}^{*}$ is the exogenous foreign wage (in terms of the numéraire). Domestic variables are denoted by $\mathrm{h}$, foreign variables by *. Using the inverse product demand curve and the equilibrium condition in the typical output market, $\mathrm{c}^{\mathrm{I}}=\mathrm{X}^{\mathrm{h}}+\mathrm{X}^{*}$, the first-order conditions are

$$
\begin{cases}\frac{\partial \Pi^{h}}{\partial X^{h}}=\frac{\psi X^{*}}{\left(X^{h}+X^{*}\right)^{2}}-w^{h}-s=0 & \text { if } \mathrm{X}^{\mathrm{h}}>0 \\ \frac{\partial \Pi^{*}}{\partial X^{*}}=\frac{\psi X^{h}}{\left(X^{h}+X^{*}\right)^{2}}-w^{*}-s=0 & \text { if } \mathrm{X}^{*}>0\end{cases}
$$

Eq. (1) defines the two best reply functions in implicit form. As is well known, with Cobb-Douglas preferences and Cournot competition in homogeneous products, these are hump-shaped in the quantity space (for example, Bhagwati et al., 1998: 388-92). This implies that the larger or low-cost (smaller or high-cost) firm views the products as strategic complements (substitutes). These properties of the model give raise to strategic interactions that are crucial for the paper's results, as shown below. The solution to Eq. (1) yields 
the equilibrium price $\mathrm{p}^{\mathrm{I}}=\mathrm{W}^{\mathrm{h}}+\mathrm{w}^{*}+2 \mathrm{~s}$ and outputs: $\mathrm{X}^{\mathrm{h}}=\psi\left(\mathrm{w}^{*}+\mathrm{s}\right) /(\mathrm{p})^{\mathrm{I}}$ for the home firm, $\mathrm{X}^{*}=\psi\left(\mathrm{w}^{\mathrm{h}}+\mathrm{s}\right) /(\mathrm{p})^{\mathrm{I}}$ for the foreign firm. Indirect profits for the domestic and foreign firms are, respectively: $\stackrel{\wedge}{\Pi^{h}}=\mathrm{X}^{\mathrm{h}}\left[\mathrm{p}-\left(\mathrm{w}^{\mathrm{h}}+\mathrm{s}\right)\right]=$

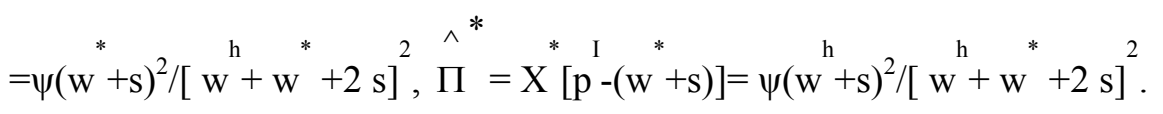

Turning to the wage stage, the home firm and union choose the wage rate strategically, by anticipating its effect on the output game. The bargaining process is represented by a standard asymmetric Nash bargaining solution. The union's objective function is assumed to be rents: $A^{\mathrm{h}}=\left(\mathrm{w}^{\mathrm{h}} / \mathrm{P}-\theta\right) \mathrm{X}^{\mathrm{h}}$, namely the product between the union wage premium and union employment. As long as the union anticipates that the firm's "labour demand" will act as a constraint on the wage choice, its objective is: $\mathrm{A}^{\mathrm{h}}=\left(\mathrm{w}^{\mathrm{h}} / \mathrm{P}-\theta\right) \psi\left(\mathrm{w}^{*}+\mathrm{s}\right) /\left[\mathrm{w}^{\mathrm{h}}+\mathrm{w}^{*}+2 \mathrm{~s}^{2}\right.$. The firm maximises CPI-indexed indirect profits. Fall-back utilities are normalised to zero for both parties, implying that during a temporary negotiation breakdown there is no utility flow for either party. The typical firm and union are small relatively to the import sector and the economy. Thus, they perceive $\mathrm{P}, \mathrm{w}^{*}$ and $\psi$ as being exogenous variables. Accordingly, the outcome of the wage bargaining solves the problem

$$
w^{h} \quad \operatorname{argmax} \mathrm{NA}=\left[A^{h}\right]^{z}\left[\Pi^{h \wedge} / P\right]^{1-z}=K\left(\mathrm{w}^{\mathrm{h}} / P-\theta\right)^{z}\left[w^{h}+w^{*}+2 s\right]^{-2},
$$

where $\mathrm{K}=\psi\left(\mathrm{w}^{*}+\mathrm{s}\right)^{2-\mathrm{z}} / \mathrm{P}^{1-\mathrm{z}}>0$ is taken as a constant by the negotiators, yielding

$$
\frac{w^{h}}{P}=\theta+\left(\frac{z}{2-z}\right)\left(\theta+\frac{w^{*}+2 s}{P}\right)
$$

The optimal CPI-indexed wage is a mark-up over the reservation wage and is an increasing function of the union's bargaining power parameter $\mathrm{z} \in[0,1]$, as one would expect. For $\mathrm{z}=0$, Eq. (2) corresponds to the nonunion wage; for $z=1$ to the monopoly union wage. The optimal wage is an increasing function of the specific tax rate $s$. This is because, with a constant-elasticity product demand curve, the elasticity of the optimal employment rule is a decreasing function of the tax rate. The equilibrium price and outputs are:

$$
\frac{\mathbf{p}^{\mathbf{I}}}{P}=\left(\frac{2}{2-z}\right)\left(\theta+\frac{w^{*}+2 s}{P}\right)
$$

\footnotetext{
${ }^{4} \mathrm{The} \mathrm{j}^{\text {th }}$ index is dropped for notational simplicity throughout. It will be reintroduced at the end of this section.
} 


$$
\begin{aligned}
& \mathbf{X}^{\mathbf{h}}=\psi\left(\frac{2-z}{2}\right)^{2}\left[\frac{w^{*}+s}{\left[\theta P+w^{*}+2 s\right]^{2}}\right] \\
& \mathbf{X}^{*}=\psi\left(\frac{2-z}{2}\right)\left[\frac{\theta P+(z / 2)\left(w^{*}+s\right)+s}{\left[\theta P+w^{*}+2 s\right]^{2}}\right]
\end{aligned}
$$

From Eq.s (3) it turns out that, in the neighbourhood of the no-excise tax equilibrium with $s=0$, the foreign firm is larger than the home firm, $\mathrm{X}^{*}>\mathrm{X}$, when $\theta \mathrm{P}>(1-\mathrm{z}) \mathrm{w}^{*}$. Thus, other things being equal, the higher is the home reservation wage $\theta \mathrm{P}$, the higher is union power $z$, the lower is the foreign wage $\mathrm{w}^{*}$, the larger the foreign firm will be vis-à-vis the home firm. Clearly, $\theta \mathrm{P}>_{\mathrm{W}} *$ is a sufficient condition for the foreign firm to be larger than the domestic firm. This condition means that, in no-union equilibrium with free trade, the foreign firm is more efficient than the domestic firm is. This assumption is made henceforth. Proposition 1 summarises the effects of a marginal increase in the excise tax rate on equilibrium.

Proposition 1: Profitable excise taxation in the import sector. A marginal increase in the excise tax rate, evaluated at $s=0$ : i) raises domestic output, if the home firm is sufficiently smaller than the foreign firm, or $\theta \mathrm{P}>3 \mathrm{w}^{*}$; ii) lowers imports, if the foreign firm is larger than the home firm; iii) lowers consumption; iv) raises the domestic wage rate; v) raises industry price by more than $100 \%$ : the degree of tax over-shifting is increasing in the union bargaining power parameter $\mathrm{z}$; vi) raises the union's utility and home profits and lowers foreign profits if $\theta P>w^{*}$.

Proof: See Appendix A.

Proposition 1 extends the analysis made by Seade (1985: 17-20), Kimmel (1992: 443-44), Anderson et al. (2001: 182) and Février and Linnemer (2004: 839-40, Cor. 3.1) among others of the equilibrium impact of a common marginal cost shock in an asymmetric Cournot oligopoly to the case of a unionised international duopoly. Proposition 1v) states that, for given consumer price index, the excise duty is over-shifted. This means that the consumer's gross price rises by more than the amount of the excise: $\mathrm{dp}^{\mathrm{I}} / \mathrm{ds}^{\mathrm{a}}=4 /(2-\mathrm{z})>1$. The degree of tax over-shifting is increasing in the union bargaining power parameter $z$. Although double marginalisation amplifies the degree of tax over-shifting (Adachi and Ebina, 2014: 172-173), this latter 
depends on the curvature of demand. ${ }^{5}$ As firstly noticed by Seade (1985: 21) and Kimmel (1992: 444), tax over-shifting opens up the possibility of a profitable cost increase whenever the fringe firm is sufficiently small at the pre-shock equilibrium. Here, for the tax shock to become profitable for home producers, it is sufficient that the domestic reservation wage is higher than the foreign wage, $\theta \mathrm{P}>\mathrm{W}^{*}$ (see Proposition 1vi and Eq.s a.5-a.6 in the Appendix A). This condition means that the domestic firm is smaller, thus less efficient, than the foreign firm is. The economic intuition is that, when $\theta \mathrm{P}>\mathrm{W}^{*}$, a marginal increase in the excise tax penalises the more efficient foreign firm, as long as it shifts market share towards the less efficient domestic firm. This is because the common increase in the marginal cost of serving the market is larger in percentage terms for the low marginal cost foreign firm (producing at $\mathrm{w}^{*}+\mathrm{s}$ ) compared to the high marginal cost domestic firm (producing at $\mathrm{w}^{\mathrm{h}}+\mathrm{s} \geq \theta \mathrm{P}+\mathrm{s}$ from Eq. 2). In other words, the marginal cost of sales for the foreign firm rises by a greater percentage than the increase in the domestic firm's marginal cost of sales. This drives the increase in the home firm's market share $\mathrm{X}^{\mathrm{h}} /\left(\mathrm{X}^{\mathrm{h}}+\mathrm{X}^{*}\right)=\left(\mathrm{w}^{\mathrm{h}}+\mathrm{s}\right) /\left(\mathrm{w}^{\mathrm{h}}+\mathrm{w}^{*}+2 \mathrm{~s}\right)$, that is $\partial\left[\mathrm{X}^{\mathrm{h}} /\left(\mathrm{X}^{\mathrm{h}}+\mathrm{X}^{*}\right)\right] / \partial \mathrm{s}=\left[\left(\partial \mathrm{w}^{\mathrm{h}} / \partial \mathrm{s}\right)\left(\mathrm{w}^{*}+\mathrm{s}\right)+\left(\mathrm{w}^{*}-\mathrm{w}^{\mathrm{h}}\right)\right] /\left[\mathrm{w}^{\mathrm{h}}+\mathrm{w}^{*}+2 \mathrm{~s}\right]^{2}>0$. This effect is always associated with lower imports (Proposition 1ii) and may be associated with higher domestic output as well if the domestic firm is largely inefficient, thus much smaller than the foreign firm at the initial equilibrium (Proposition 1i). This result is related to the strategic response of foreign and domestic outputs to the tax shock: with a unit-elastic demand curve and Cournot competition, the strategic effect for the less-efficient domestic firm is to increase its own output, and this effect may dominate the direct reduction in home output provoked by the tax. ${ }^{6}$ In this case, domestic excise taxation operates as a protectionist device. However, even if home production falls after the tax shock, domestic rents become higher if the increase in the home market share is coupled with price over-shifting, which is the case with a unit-elastic industry demand when the home firm is smaller, thus less efficient, than the foreign firm (namely, for $\left.\theta \mathrm{P}>\mathrm{w}^{*}\right)$. Note that, had the two firms equal size $\left(\mathrm{w}^{\mathrm{h}}=\mathrm{w}^{*}\right)$, tax over-shifting would leave profits unaffected here (Fullerton and Metcalf, 2002: 31).

\footnotetext{
${ }^{5}$ With exogenous marginal costs, tax shifting is given by (Delipalla and Keen, 1992): $\mathrm{dp} / \mathrm{ds}=1 /[1-1 /(\varepsilon \mathrm{m})]$, where $\varepsilon$ is the absolute value of the price elasticity of industry demand and $\mathrm{m}$ is the number of active Cournot firms.

${ }^{6}$ The smaller domestic firm views products as strategic substitutes (namely, it has a downward sloping best reply function in output space at the initial equilibrium), whereas the larger foreign firm views them as strategic complements (namely, upwards sloping best reply). Thus, the strategic effect induces the domestic firm to expand its own output.
} 
Let us now discuss the role of unions. When $\theta \mathrm{P}>\mathrm{W}^{*}$, a profitable tax increase occurs irrespective of unionisation (namely, even if $\mathrm{z}=0$ ) here. Unionisation, however, affects not only the distribution of rents between domestic producers, but also the size of rent shifting and the likelihood that this occurs at the industry level. In partial equilibrium, if one takes the general price level $\mathrm{P}$ and national income as given, an increase in the tax rate leads to a bigger increase in domestic rents when union power is higher. Double marginalisation means that tax over-shifting- thus the tax-induced increase in the domestic market share- is the larger, the higher union bargaining power is. Of course, a more powerful union allows workers to take away a bigger share of product market rents from firms in terms of higher wages. ${ }^{7}$ This latter effect, together with the assumption of a rent-maximising union, explains why the union is always made better off by the excise: union's utility increases irrespective of whether domestic employment rises (for which one would need $\theta \mathrm{P}>3 \mathrm{w}^{*}$ ) or falls (implying $3 \mathrm{w}^{*}>\theta \mathrm{P}>\mathrm{w}^{*}$ ). However, unionisation has also general equilibrium effects, which feedback at the industry level. More specifically, under "right-to-manage" the general price level P is an increasing function of the union bargaining power parameter, or $\mathrm{d} \ln \mathrm{P} / \mathrm{dz}>0$ (see Eq.b11 in Appendix B for a proof). Thus, other things being equal, one would expect that higher union power will be associated with higher industrial wages both directly and because of the effect on P. This implies that, in the current model, the higher is the degree of unionisation, as being summarised by the parameter $\mathrm{z}$, the higher is the CPI and the more likely is that the condition for a profitable excise tax increase is satisfied in partial equilibrium.

In a symmetric equilibrium in the import sector, each industry $\mathrm{j}$ chooses the same wage, price, output

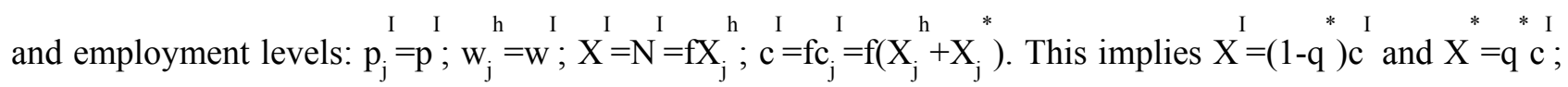
$\mathrm{q}^{*}=\mathrm{X}^{*} /\left(\mathrm{X}^{\mathrm{h}}+\mathrm{X}^{*}\right) \equiv\left[\theta \mathrm{P}+(\mathrm{z} / 2)\left(\mathrm{w}^{*}+\mathrm{s}\right)+\mathrm{s}\right] /\left[\theta \mathrm{P}+\mathrm{w}^{*}+2 \mathrm{~s}\right]$ is the typical foreign firm's market share, and $\mathrm{c}^{\mathrm{I}}=\beta \Omega / \mathrm{p}^{\mathrm{I}}$, where $\mathrm{p}$ is given by Eq. (3.1).

To recap, this section has shown the conditions thereby home producers can be made better off by excise taxation. With unit-elastic industry demand, both fringe domestic firms and unions in the typical industry perceive gains from taxation and potentially have independent incentives to lobby the government for an excise duty. Section 5 will analyse this issue by considering lobbying by part of confederations of firms and

\footnotetext{
${ }^{7}$ For $\theta \mathrm{P}>\mathrm{W}^{*}$, both the reduction in the foreign profits and the increase in the home profits are a decreasing function
} 
unions, both organised at the sectoral level. Sectoral lobbies will behave differently from individual firms and unions because they will be aware of the general equilibrium effects of the tax. The next section will consider the government's incentives to choose the excise tax rate optimally in the absence of lobbying.

\section{Optimal excise tax rate without lobbying}

This section sketches the general equilibrium solution of the model and considers the tax rate that the selfinterested government would optimally set if no lobbies existed. This corresponds to the case of a Leviathan maximising CPI-indexed tax revenues, which it ships abroad or consumes directly. An excise tax seems the most effective revenue-raising tool for a self-interested Leviathan, as long as it is easy to administer and collect and is politically acceptable (Cnossen, 2005: 3). Moreover, international agreements (for example, the presence of a common market and antitrust legislation in the EU) are likely to prevent the government from using alternative tax instruments, such as a tariff-equivalent tax (namely, a consumption tax and a production subsidy for home firms set at the same rate) for both raising revenue and protecting domestic producers.

Assume balanced trade. This implies that the value of exports must be equal to the value of imports, namely, $X^{\mathrm{E}}-c^{\mathrm{E}}=\left(\mathrm{p}^{\mathrm{I}}-\mathrm{s}\right) \mathrm{q}^{*} \mathrm{c}^{\mathrm{I}}$. This yields equilibrium national income $\Omega$ :

$\Omega=\frac{X^{E}}{1-\beta(1-n)}$

In Eq. (4), $n=q^{*}\left[\left(p^{I}-s\right) / p^{I}\right]$ is the effective marginal propensity to import, corresponding to the market share of the typical foreign firm when $\mathrm{s}=0$, as long as $\mathrm{q}^{*}=\mathrm{X}^{*} /\left(\mathrm{X}^{\mathrm{h}}+\mathrm{X}^{*}\right)$. Because of the assumptions of log-linear preferences, constant marginal product of labour in the import sector, constant disutility of labour and underemployment in the economy, the relative prices can be solved independently of the quantities. This implies that prices, wages, and the export sector's output level are fixed in equilibrium, for given policy parameters. Export sector output can be written as an implicit function of the exogenous and policy variables and parameters $X^{\mathrm{E}}=\mathrm{X}^{\mathrm{E}}\left(\alpha, \theta, \beta, \mathrm{z}, \mathrm{w}^{*}, \mathrm{~s}\right)$.

The Leviathan chooses the excise rate maximising the CPI-indexed value of revenues, namely in terms

of $z$, while the union's utility is an increasing function of $z$, see Eq.s (a.5) and (a.6) in Appendix A. 
of the consumption goods index. ${ }^{8}$ Using $P=\left(p^{I}\right)^{\beta}$, this is given by: $R / P=s\left(X^{I}+X^{*}\right) / P=s \beta \Omega /(p)^{I+\beta}$. The FOC is

$$
\frac{d R / P}{d s}=\frac{R}{P}\left[\frac{1}{s}-\left((1+\beta) \frac{d \ln p^{I}}{d s}-\frac{d \ln \Omega}{d s}\right)\right]=0
$$

Eq. (5) has a standard interpretation: the revenue-maximising tax rate is obtained when the elasticity of the tax base (namely, domestic consumption of the excisable good) with respect to the tax rate is equal to minus unity. Alternatively, one can interpret the first term on the RHS as the marginal benefit of the excise, whereas the RHS second round bracketed term as the corresponding marginal cost. From the Leviathan's point of view, in general equilibrium, this latter cost depends on how both the national income and the import price (affecting the tax base), and the consumption price index (affecting the CPI-indexed value of the duty rate) vary with the tax. The optimal tax rate $s$ in implicit form is:

$$
\hat{s}=\left[(1+\beta) d \ln p^{I} / d s-d \ln \Omega / d s\right]^{-1}
$$

As long as the RHS term of this equation has a positive sign, the excise rate is the higher: the lower is the tax-induced increase in the Cournot price, thus the lower is the consumer price index spillover effect (which is proportional to $\beta$ ); and the lower (higher) is the reduction (increase) in national income, other things being equal. The Appendix B derives the general equilibrium effects of a marginal increase in the excise duty. Using these results, the RHS term writes:

$$
M C \equiv(1+\beta) \frac{d \ln p^{I}}{d s}-\frac{d \ln \Omega}{d s}=\left[1+\frac{\beta}{1-\alpha}\right] \frac{d \ln p^{I}}{d s}+\left\{\frac{\beta n}{1-\beta(1-n)}\right\} \frac{d \ln n}{d s}>0
$$

In Eq. (6), the RHS first term is always positively signed and is independent of the foreign firm's market size (see Eq. b.9 in Appendix B). The sign of the RHS second term depends on the effects of the excise duty on the marginal propensity to import $n$, which in turn depends on the initial foreign firm's market share. If the foreign firm is sufficiently larger than the home firm in the typical industry, the marginal effect of the tax on the marginal propensity to import is negative (see Eq.s b.1 and b.2 in Appendix B). The sum of the two terms

\footnotetext{
${ }^{8}$ EC (2004: 17-19) is an example of EU member states' concern for the CPI value of the excise tax rates they set; Lockwood and Migali (2009: 413) provide an empirical application. In Australia, excise taxes on alcohol are CPIindexed: www.ato.gov.au/Business/Excise-and-excise-equivalent-goods/Alcohol-excise/Excise-rates-for-alcohol/
} 
of $\mathrm{MC}$, if evaluated in the neighbourhood of the no tax equilibrium $\mathrm{s}=0$, is positively signed irrespective of the relative market size (see Eq. b.10 in Appendix B). However, the optimal excise duty will be higher when the equilibrium marginal propensity to import falls with the tax rate, yielding

Proposition 2 Leviathan's optimal excise rate. A sufficient condition for the marginal propensity to import to be a decreasing function of the excise tax rate is that, in the neighbourhood of the no-tax equilibrium, $\theta \mathrm{P} \geq \mathrm{W}^{*} \mathrm{~K}_{0}$, where $\mathrm{K}_{0} \equiv(2-\mathrm{z}) /[(2+\mathrm{z})(1-\beta)]$ and $\partial \mathrm{K}_{0} / \partial \beta>0$ and $\partial \mathrm{K}_{0} / \partial \mathrm{z}<0$. When this condition is satisfied, the Leviathan optimal excise tax rate is an increasing function of the degree of foreign penetration in the domestic market.

Proof. See Appendix B for the first part. The second part follows from Eq. (6).

Proposition 2 states that, when the typical foreign firm is sufficiently larger than the home firm, the Leviathan government has the incentive to set a higher optimal excise rate than it would do had the two firms equal size. ${ }^{9}$ In this situation, the higher is the degree of import penetration, the higher is the optimal tax rate. Intuitively, when the marginal propensity to import falls, equilibrium national income increases (see Eq. 4). This raises both domestic consumption and tax revenues other things being equal. However, an increase in the excise rate allows the home firm to steal market share from the foreign firm, if and only if the latter is larger (see section 2.1 above). The exact condition depends as well on the size of the import sector, determining the size of the spillover effect from the imports price to the CPI. In turn, this spillover affects the size of the feedback effects on prices, wages and economic activity in each sector. ${ }^{10}$ For given union bargaining power $z$, an increase in the size of the import sector $\beta$ implies a larger price spillover. Thus, in the pre-tax equilibrium the home firm must be much smaller than the foreign firm for the marginal propensity to import to fall with the tax. For given size of the import sector $\beta$, higher union power z makes it more likely that the excise tax lowers the marginal propensity to import. Intuitively, unionisation makes the initial foreign firm's market share larger, other things being equal. Thus, the gap between $\theta \mathrm{P}$ and $\mathrm{w}^{*}$ can be smaller for the condition to be satisfied.

\footnotetext{
${ }^{9}$ Proposition 2 assumes that, using Eq. (5), the second order condition for a maximum is satisfied.

${ }^{10}$ Recall that the size of the import sector does not influence the condition for a profitable tax increase. This is because each home producer, being small, does not perceive the general equilibrium effects of the policy.
} 
To recap, this section suggests that a government maximising the CPI-indexed excise tax revenue will set a higher excise tax rate when both the domestic production is residual relatively to foreign imports and the excisable good import sector is not too large, other things being equal. Because this policy implies rentshifting from foreign to domestic producers in the import sector as well, the government behaves as if it were quasi-utilitarian, given that it disregards consumer surplus altogether. Moreover, as long as the policy makes domestic producers better off, they will welcome it. The next session addresses this issue.

\section{Lobbying for excise taxation}

This section presents a simplified model à la Grossman and Helpman (2002) based on Palokangas (2003) in order to consider how lobbying for protective taxation may affect the optimal excise tax rate chosen by a self-interested government. In the import sector, domestic firms are assumed to be able to form a lobby (an employers' confederation) representing industry interests and similarly the domestic unions organise themselves into a unions' confederation. Each lobby in the import sector links its contributions to the government's tax policy. Namely, Grossman and Helpman's (2002: 190) "focused lobbying effort" assumption holds. In the export sector, firms and workers are assumed to undertake no lobbying: as long as there is a large number of them, they cannot solve free riding problems.

To characterise the political equilibrium, the sequence of events is as follows. Initially, each lobby simultaneously and independently chooses contribution schedules, ME(s) for the employers and MU(s) for the unions, both expressed in CPI terms, linking payments made to the government to its excise tax policy. Thus, the lobbies play Nash against each other, behaving like principals that aim at influencing the subsequent policy of the government, who acts as their common agent. Then, the government sets the tax policy in order to maximise the sum of its tax revenue and the lobbies' contributions. ${ }^{11}$ All agents anticipate the effects of the tax policy on the subsequent market equilibrium. Thus, the two confederations of

\footnotetext{
${ }^{11}$ Grossmann and Helpman (2002: 119) assume that the government cares about aggregate social welfare. This is justified by claiming that the government is either partly benevolent or concerned about the next election. Here, one can think of the government believing that the excise is not a salient issue affecting its re-election probability. As a result, it disregards domestic consumer surplus altogether. Moreover, the government cares about firms' profits and unions' utility in the import sector because of lobbying.
} 
employers and unions, unlikely their single members in isolation, are able to correctly anticipate general equilibrium effects. Total net welfare of all firms and unions is, respectively:

$$
\begin{aligned}
& \frac{\hat{\Pi(s ;)}}{P} \equiv \sum_{j=1}^{f}\left(\frac{\Pi_{j}^{h}}{P}\right)-M E(s) \equiv \frac{\Pi^{I}(s ;)}{P}-M E(s)=\left(p^{I}-w^{I}-s\right)\left(1-q^{*}\right) \frac{c^{I}}{P}-M E(s) \\
& \hat{\wedge} \\
& \frac{A(s ;)}{P} \equiv \sum_{j=1}^{f} A_{j}{ }^{h}-M U(s) \equiv A^{I}(s ;)-M U(s)=\left(\frac{w^{I}}{P}-\theta\right)\left(1-q^{*}\right) c^{I}-M U(s)
\end{aligned}
$$

$\mathrm{q}^{*}=\mathrm{X}^{*} /\left(\mathrm{X}^{\mathrm{h}}+\mathrm{X}^{*}\right), \mathrm{c}^{\mathrm{I}}=\beta \Omega / \mathrm{p}^{\mathrm{I}} ; \mathrm{\text {w }} / \mathrm{P}, \mathrm{p}^{\mathrm{I}} / \mathrm{P}, \mathrm{X}^{\mathrm{h}}, \mathrm{X}^{*}, \Omega$ follow from Eq.s (2) to (4). With lobbying, the government maximises:

$$
G(s)=M E(s)+M U(s)+\frac{R}{P}=M E(s)+M U(s)+s \beta \Omega /\left(p^{I}\right)^{1+\beta}
$$

Because the government is purely self-interested, its marginal rate of substitution between contributions and tax revenue is unity. Following Grossman and Helpman (2002, Proposition 1: 120) and Palokangas (2003: 259), define a sub-game perfect Nash equilibrium of the lobbying game as a set of contribution functions, $\mathrm{ME}^{\circ}(\mathrm{s})$ and $\mathrm{MU}^{\circ}(\mathrm{s})$, and a tax policy $\mathrm{s}^{\circ}$ that satisfies the following conditions: i) contributions are feasible, namely they are non negative and less than the total income of the lobby. ii) The optimal tax policy $s^{\circ}$ maximises the government objective function, given the contributions of the two lobbies. iii) For each lobby, the tax policy maximises the sum of the government's and that lobby's welfare, given the other lobby's contribution. iv) A participation condition for the government holds: each lobby gives the government at least the level of utility it could get when the lobby offers nothing and the government sets its policy optimally, given the other lobby's contribution.

By assuming that contribution functions are differentiable around the equilibrium point $\mathrm{s}^{\circ}$, conditions ii) and iii) imply that the contribution schedules are locally truthful (thus the Nash equilibrium will be unique). Each lobby offers its true willingness to pay for marginal changes in the excise tax rate in equilibrium. This implies that at $\mathrm{s}^{\circ}$ each lobby sets its contributions such that the marginal change in its contribution, due to a small change in the tax rate around the optimum, is equal to the change in the lobby's gross welfare provoked by this policy change, yielding (see Appendix C for a derivation): 


$$
\begin{aligned}
& \frac{d \Pi^{I}\left(s^{o}\right) / P}{d s}=\frac{d M E\left(s^{o}\right)}{d s} \\
& \frac{d A^{I}\left(s^{o}\right)}{d s}=\frac{d M U\left(s^{o}\right)}{d s}
\end{aligned}
$$

When the contribution schedules are differentiable around the equilibrium point, ${ }^{12}$ it follows that the government chooses the tax rate as if it maximised the sum of its own objective function and of the two lobbies' (see Appendix C). Thus, the optimal tax rate satisfies the first-order condition:

$$
\frac{d \Pi^{I}\left(s^{o}\right) / P}{d s}+\frac{d A^{I}\left(s^{o}\right)}{d s}+\frac{d R\left(s^{o}\right) / P}{d s}=0
$$

From Eq. (10), a marginal excise tax change affects the lobbies' welfare through three channels. Firstly, it affects the price $d\left[\left(\mathrm{p}^{\mathrm{I}}-\mathrm{I}-\mathrm{w}-\mathrm{s}\right) / \mathrm{P}\right] / \mathrm{ds}$ and wage $\mathrm{d}\left(\mathrm{w}^{\mathrm{I}} / \mathrm{P}-\theta\right) / \mathrm{ds}$ mark-ups. For given consumer price index $\mathrm{P}$, both lobbies gain from a higher tax rate, as long as the domestic price exceeds the wage, whereas the marginal disutility of work is fixed. However, because of tax-induced general price inflation, $\mathrm{dln} P / \mathrm{ds}=\beta \mathrm{d} \operatorname{lnp} / \mathrm{I} / \mathrm{ds}>0$, the CPI-indexed price and wage mark-ups both fall, thus lowering the lobbies' gain. Second, there is a foreign market share effect, $\mathrm{d}(1-\mathrm{q}) / \mathrm{ds}$. For given $\mathrm{P}$, the domestic lobbies gain (lose) market share from a higher tax rate, if the typical foreign firm is larger (smaller) than the typical home firm. However, more price inflation, by pushing the domestic wage up relatively to the foreign wage, raises the foreign market share, thus reducing such a gain. Finally, there is a demand effect dc/ds (see Eq. 6 above and Eq. b.5 in Appendix B). After appropriate substitutions, the optimal excise tax rate solves

$$
\begin{aligned}
\frac{d \Pi^{I} / P}{d s}+\frac{d A^{I}}{d s}+\frac{d R / P}{d s}= & \left.\frac{p^{I}-s}{P}-\theta\right)\left(1-q^{*}\right) c^{I}\left\{\frac{d \ln \left(\left(p^{I}-s\right) / P-\theta\right)}{d s}+\frac{d \ln \left(1-q^{*}\right)}{d s}+\frac{d \ln c^{I}}{d s}\right\} \\
& +\frac{R}{P}\left[\frac{1}{s}-\left((1+\beta) \frac{d \ln p^{I}}{d s}-\frac{d \ln \Omega}{d s}\right)\right]=0
\end{aligned}
$$

The terms in curly brackets on the RHS of Eq. (11) represent the effects of the excise tax on the gross

\footnotetext{
${ }^{12}$ A truthful contribution schedule reflects everywhere the lobby's true preferences, It indicates the relationship between the contribution paid and the tax rate $s$ set by the government, namely the excess of the lobby's gross welfare at that tax rate relatively to the welfare level the lobby would get by paying no contributions when the government chooses its policy as a best response to the other lobby's contribution, Palokangas (2003: 260).
} 
welfare of the two lobbies, while the RHS last term gives the impact on the CPI-indexed tax revenue. From Proposition 2 above, this latter term determines the Leviathan optimal tax rate in the absence of lobbying. Considering the terms in curly brackets, notice that the first term is positive; the second term is positive provided that the tax lowers the typical foreign firm's market share (namely, if $\partial \mathrm{q}^{*} / \partial \mathrm{s}<0$ and $\mathrm{d}(\mathrm{p}$ I $/ \mathrm{P}) / \mathrm{ds}=(1-$ $\beta$ )dp ${ }^{\mathrm{I}} / \mathrm{ds}>0$ ), whereas the third term is the demand effect (see Eq. b.12 in Appendix B). Eq. (11) cannot be signed in general, which may imply the government's choosing a tax rate that is either higher or lower than the rate it would choose had lobbies not existed. However, it is easy to derive a sufficient condition thereby the gross welfare of the two lobbies increases (implying that the expression in curly brackets is positively signed), which means that the lobbies would unambiguously jointly push the self-interested government to set a higher tax rate than if it acted as a Leviathan. This sufficient condition is summarised in Proposition 3.

Proposition 3. Lobbying for excise taxation. A sufficient condition for lobbying to induce the self-interested government to choose a higher tax rate than if it acted as a Leviathan is $\theta P \geq\left(w^{*}\right) K_{2}$, where,

$$
K_{2} \equiv \max \left\{K_{0} \equiv \frac{(2-z)}{(2+z)(1-\beta)} ; K_{1} \equiv\left[\frac{2+\beta+\frac{2 \alpha}{1-\alpha}+\sqrt{\left(2+\beta+\frac{2 \alpha}{1-\alpha}\right)^{2}+4(1-\beta)\left[3+\frac{2 \alpha \beta}{1-\alpha}\right]}}{2(1-\beta)}\right]\right\}
$$

with $\mathrm{K}_{1}>\mathrm{K}_{0}$ for $\alpha \geq 0.4$,

Proof: See Eq. (b.12) in Appendix B.

The interpretation of the sufficient condition of Proposition 3 is as follows. The two lobbies will welcome an increase in the excise tax rate if the following conditions occur. First, an increase in the excise tax rate must raise the price mark-up of domestic producers, namely $\mathrm{p}^{\mathrm{I} / \mathrm{P}-\theta}$, for given home firm's output. A sufficient condition for this to occur is $\theta \mathrm{P} \geq\left(\mathrm{w}^{*}\right) \mathrm{K}_{0}$ (see Eq. b.12 in Appendix B), with $\partial \mathrm{K}_{0} / \partial \mathrm{z}<0$ and $\partial \mathrm{K}_{0} / \partial \beta>0$. The intuition is that the higher is the union bargaining power $\mathrm{z}$, the higher is the pass-through of tax hikes to the consumer gross price, the more likely is that the price mark-up increases with the tax, other things being equal. However, the higher is the import sector size $\beta$, the higher is the price spillover on the CPI, which 
lowers the CPI-indexed producer price, other things being equal. Second, an increase in the excise tax must lower the foreign market share. In general equilibrium $\theta \mathrm{P} \geq \mathrm{w}^{*}(1+\beta) /(1-\beta)$ is sufficient for this to be the case (Eq. b.2 in Appendix B). This condition is more restrictive than the one derived in partial equilibrium (namely, $\theta \mathrm{P}>\mathrm{W}^{*}$ ). The intuition is that the larger the size of the import sector $\beta$, the bigger the general price spillover effect of a marginal increase in the tax rate, other things being equal. As a result, the lower the gain in CPI terms for import sector producers of a higher protective excise, other things being equal. Third, the reduction in domestic consumption in the import sector must not be too large. However, other things being equal, the higher is the labour elasticity of export sector output $\alpha$, the bigger is the tax-induced reduction in export sector output, the bigger is the reduction in national income and domestic consumption (see Eq.s b.3b.5 in Appendix B). Thus, a higher value of $\alpha$ makes the sufficient condition of Proposition 3 more restrictive.

Table 1. Critical value of $K_{1}$ such that domestic lobbying pushes for higher excise taxes

\begin{tabular}{|l|l|l|l|l|l|l|l|l|l|}
\hline & $\boldsymbol{\beta}=\mathbf{0 . 1}$ & $\boldsymbol{\beta}=\mathbf{0 . 2}$ & $\boldsymbol{\beta}=\mathbf{0 . 3}$ & $\boldsymbol{\beta}=\mathbf{0 . 4}$ & $\boldsymbol{\beta}=\mathbf{0 . 5}$ & $\boldsymbol{\beta}=\mathbf{0 . 6}$ & $\boldsymbol{\beta}=\mathbf{0 . 7}$ & $\boldsymbol{\beta}=\mathbf{0 . 8}$ & $\boldsymbol{\beta}=\mathbf{0 . 9}$ \\
\hline $\boldsymbol{\alpha}=\mathbf{0 . 4}$ & 4.585 & 5.202 & 5.999 & 7.057 & 8.526 & 10.719 & 14.375 & 21.607 & 43.302 \\
\hline $\boldsymbol{\alpha}=\mathbf{0 . 5}$ & 5.245 & 5.963 & 6.889 & 8.114 & 9.815 & 12.550 & 16.553 & 24.923 & 49.961 \\
\hline $\boldsymbol{\alpha}=\mathbf{0 . 6}$ & 6.363 & 7.131 & 8.247 & 9.720 & 11.765 & 14.810 & 19.856 & 29.903 & 59.951 \\
\hline $\boldsymbol{\alpha}=\mathbf{0 . 7}$ & 8.003 & 9.114 & 10.539 & 12.419 & 15.09 & 18.916 & 25.356 & 38.18 & 76.533 \\
\hline $\boldsymbol{\alpha}=\mathbf{0 . 8}$ & 11.594 & 13.186 & 15.11 & 17.91 & 21.646 & 27.216 & 36.453 & 54.857 & 109.928 \\
\hline $\boldsymbol{\alpha}=\mathbf{0 . 9}$ & 22.5806 & 25.573 & 29.408 & 34.493 & 41.577 & 52.161 & 69.746 & 104.830 & 209.914 \\
\hline
\end{tabular}

Proposition 3. This condition is sufficient for domestic lobbies to push for higher excise taxation than a taxrevenue maximising Leviathan would choose.

Table 1 above presents numerical examples showing the value of the $K_{1}$ parameter, for given values of 
$1>\alpha \geq 0.4$ (the export sector's output elasticity of labour) and $\beta$ (the size of the import sector) parameters. These examples confirm that $\partial \mathrm{K}_{1} / \partial \alpha>0$ and $\partial \mathrm{K}_{1} / \partial \beta>0$. Note that $\mathrm{K}_{1}>\mathrm{K}_{0}$ for $\alpha \geq 0.4$. It follows that for domestic producers to lobby for protective excise taxation, the foreign firm must be largely dominant in the industry before the introduction of the tax. For example, if $\alpha=0.7, \beta=0.1$ and $z=0.5$, the foreign market share in the no-tax equilibrium must be equal to $1>\mathrm{q}^{*}=\left[\theta \mathrm{P}+(\mathrm{z} / 2) \mathrm{w}^{*}\right] /\left[\theta \mathrm{P}+\mathrm{w}^{*}\right] \geq 0.92$ from Table 1 .

The analysis of this section suggest that, if domestic producers are rational and fully aware of the general equilibrium effects of the excise tax rate on prices and demand, they would lobby for excise taxation only when domestic production is much smaller than domestic demand. In other words, domestic lobbying occurs when foreign firms are largely dominant and more efficient at the margin than domestic firms.

\section{Discussing the paper's main assumptions and policy implications}

The results derived in this paper are based on a number of assumptions: a self-interested government setting a specific excise tax, imperfectly competitive Cournot product markets, unit-elastic demand curves, segmented labour markets with domestic union wage bargaining, union rent maximisation and exogenous foreign marginal costs. Although this is a highly stylized model, it is useful to discuss whether these assumptions capture reasonably characteristic features of markets with excise taxation. This way, one can assess whether or not it is possible to derive any policy implication from the model, especially for the EU.

As is well known, specific excise taxation is typically observed in the alcohol, tobacco, fuel and motor vehicles markets. These are characterised both by market power (either with a limited number of producers, for example: cigarettes and beer, or with a larger number of producers, for example: wine) and by inelastic or unit elastic demand curves. For example, in the EU alcohol taxation is fully specific, whereas tobacco taxation, unlikely in the US, is partly ad valorem. When setting the excise in these markets, EU governments are likely to care not only for the revenue raised, but also for the external costs associated with the consumption of excisable goods (Cnossen, 2006 and 2007). In the absence of consumption externalities in the current model, as already argued the assumption of a self-interested government allows us to capture the idea that excise tax setting may not only serve the two-fold purpose of raising revenue and protecting domestic producers, but it may also reflect a public-health-motivated lack of concern for consumer surplus. 
(As governments may like the idea that excise tax hikes discourage consumption, although this incentive is not modelled here.) Moreover, as long as specific taxation yields higher prices for given tax revenue and is more advantageous for profit-maximising oligopolies relatively to ad valorem taxation (Delipalla and Keen, 1992), one would expect that private producers will lobby for specific excise taxation (Delipalla and O'Donnell, 2001: 896, on the EU cigarettes market). For the same reason, governments should prefer it for public health considerations, other things being equal.

Regarding market structure and demands, the model assumptions of oligopolistic Cournot behaviour and integrated product markets seem broadly consistent with the existing empirical evidence for the EU alcohol (Bergman and Hansen, 2013) and tobacco markets (Delipalla and O’Donnell, 2001), in which however product differentiation also plays a role. The assumption of a unit-elastic product demand curve leading to tax over-shifting is also consistent with the empirical evidence for these industries. For example, Cnossen (2007: 721) quotes evidence from several country-level studies estimating the uncompensated own-price elasticity of demand in the range $-0.3 /-0.35$ for beer, $-0.68 /-1$ for wine and $-0.98 /-1.5$ for spirits. Gallet's (2007) meta-regression analysis based on 132 studies predicts a price elasticity of -0.83 for beer, -1.11 for wine and -1.09 for spirits. As regards single country results, for the US Manning et al. (1995: 138, Table 4) find a median drinker price elasticity of demand equal to -1.19. As regards the UK, Blake and Nied (1997: 1668, Table 9) report price elasticity of -0.95 for beer, -0.93 for wine and -1.32 for spirits using 1952-1991 data; Crawford et al. (1999: 298, Table 2) find -0.76 for beer, -1.69 for wine and -0.89 for spirits in 19931996; Meng et. al. (2014: 101, Table 3) for the years 2001-2009 estimate- 0.78 and -0.98 for beer, -0.871 and -0.384 for wine, and -0.89 and -0.082 for spirits considering on-trade sales and off-trade sales, respectively. For Sweden, using quarterly data for 1984-2003 based on the state alcohol monopoly's off-premise retail sales, Norström (2005: 94) reports price elasticities of -0.8 for beer, -0.6 for wine and -1 for spirits. He also quotes earlier findings for 1970-1988 of $-1.3,-0.9$ and -0.9 , respectively. As far as the demand for cigarettes is concerned, Cnossen (2006: 317 ) reports price elasticity of demand between -0.4 and -1.0 in the US and 0.1 and -0.8 in the UK. Gallus et al. (2006: 118, Table 3) find an elasticity of -0.76 using European crosscountry data for 2000 . The previous elasticity estimates are also consistent with the empirical evidence showing price over-shifting of specific taxation in the beverages and tobacco industries (Baker and 
Brechling, 1992, for wine in the UK; Besley and Rosen, 1999, for the US; Delipalla and O'Donnell, 2001, for the EU cigarettes market; Young and Bielinska-Kwapisz, 2002, for the US alcohol market; Bergman and Hansen, 2013, for the Danish beverage market; Bonnet and Réquillart, 2013, for the French soft drink market). It is worthy noticing that the partial equilibrium results of the current paper (Proposition 1) would remain qualitatively unaffected had one assumed a price inelastic demand in the range $-0.5 /-1$.

Turning to the labour market, the assumptions of segmentation or low inter-sectoral mobility and of unionisation seem reasonable for the $\mathrm{EU}$, at least in the short run. However, although union rent maximisation under right to manage is the standard assumption in both theoretical papers and empirical applications, there is limited empirical evidence regarding both union power and preferences and the bargaining scope that is based on EU industry-level data. A notable exception is Dumont et al. (2006), who investigate these features over the 1994-1998 years for twelve manufacturing sectors in five European countries (Belgium, France, Germany, Italy and the UK) using company-level annual data. For the Food, Beverages and Tobacco sector they find evidence of cross-country varying degrees of union bargaining power (corresponding to the value of $\mathrm{z}$ here), ranging from 0.25 in Italy to 0.64 in France, with a median value of 0.46 in Germany. Moreover, they show that unions in this sector seem wage oriented, estimating a preference parameter ranging from 0.24 in the UK (strong wage orientation) to 0.7 in Belgium (weak wage orientation), with a median value of 0.41 in France. It is again worthy noticing that assuming union wageorientation would not overturn our partial equilibrium analysis, although, by generating higher tax overshifting, thus more CPI inflation in general equilibrium, it would make more stringent the conditions inducing sectoral firm and union associations to lobbying for excise taxation. Finally, they find evidence in favour of a "labour-hoarding" model in which firms and unions negotiate jointly over wages and overhead labour (namely, the proportion of unproductive time a worker is paid, for example as a result of overmanning), while firms choose unilaterally the number of productive workers maximising their profits (Dumont et al., 2006: 89, Table 1). However, this finding flies in the face with evidence from the field. For example, the UK WERS Panel survey data shows that staffing levels are negotiated in less than one fifth of all private-sector unionised workplaces (Bryson, 2004: 286, Table 1 for the 1990 wave). This makes it unlikely the hypothesis of labour hoarding being a pervasive phenomenon in the Food, Beverages and 
Tobacco sectors, at least in the UK, where right-to-manage seems more likely. Finally, the assumption of an exogenous foreign wage is harder to justify in the context of EU trade and can be taken as a simplifying assumption related to the small open economy hypothesis. Allowing for a foreign wage response to domestic excise taxation would surely change the exact condition for a profitable tax increase. However, it will not change the fact that the domestic firm must have higher marginal costs than the foreign firm in order to satisfy Proposition 1.

On the basis of the previous discussion, as long as one is prepared to broadly accept the assumptions made in the current paper, one can draw empirical and policy implications for the EU. Firstly, one testable implication is that there exists a positive correlation between import penetration and excise tax rates at the industry level, other things being equal. Second, the paper predicts that this positive correlation may result both from tax revenue incentives and perhaps from the activity of domestic lobbies that are fringe competitors in the output market, as long as the size of the excisable good import sector is not too large. Considering the above cited evidence on unionisation (estimating union power parameters on cross-country averages of around 0.5 ), both explanations seem a possibility in the Food, Beverages and Tobacco sector, which in each EU-14 countries represents less than 7\% of consumer budget share over the 2000-2006 years (roughly corresponding to the first column of Table 2). Although lobbying on excise taxation in this sector is a pervasive phenomenon both in the EU and in the US, we have no circumstantial evidence to offer on lobbying for tax hikes. However, the predictions of the model are consistent with the idea that large dominant domestic firms may lobby for tax cuts or limit tax hikes.

Regarding policy implications, the analysis of this paper is a further warning on the potential dangers of excise tax harmonization in the EU. As it has already been noticed, harmonization can alter the relative competitive positions of producers that are based in various states (Cnossen, 2005: 17, on the tobacco sector). For example, the analysis of this paper suggests that a EU-led push toward excise tax hikes (for example: by setting positive minimum tax rates) would be welcomed (opposed) by firms with smaller (larger) market share in a given country, whereas a EU-led push toward tax reductions (for example: by setting a zero minimum tax rate) would be welcomed (opposed) by dominant (fringe) firms. As long as cost differentials reflect efficiency differences, raising minimum tax rates would benefit relatively inefficient producers. 


\section{Conclusion}

This paper has considered the effects of an excise duty in a two-sector partially unionised small open economy. A revenue-maximising government has incentives to set a higher excise tax rate under the destination principle the higher import penetration- thus the smaller domestic production relatively to domestic demand- and the smaller the sector's size in the national economy. This finding is consistent with the empirical observation that excise duties are higher in industries with dominant foreign production (or high import penetration), and smaller in industries with dominant home production (or small import penetration). Moreover, the result that excise tax rates tend to be higher in industries where domestic production is relatively smaller seems also consistent with Besley and Rosen's (1998, Table 2: 392-93) findings as regards federal cigarette and gasoline excise tax rates in the US. By using 1975-1989 annual data, they show that US states with relatively important tobacco industries tend to have lower tax rates on tobacco and higher tax rates on gasoline, whereas states with relatively important gasoline industries tend to have lower gasoline tax rates and higher tobacco tax rates. Similarly, Andersen (2010, Table 2: 22-23) shows that, as far as domestic excise taxes are concerned, wine consumption is not taxed at all in most European net wine exporting countries (Germany, Greece, Italy, Spain, Portugal, France being an exception), whereas it is heavily taxed in comparison with beer taxation in most European net wine importing countries (the Baltic Countries, Denmark, Finland, Ireland, the Netherlands, Poland, Sweden, the UK).

The second result of the paper is that excise taxes may emerge in political equilibrium in which domestic firms and unions lobby for protection when domestic producers have a very low domestic market share. Although there is circumstantial evidence of lobbying for profitable common cost increases in some industries (see Mason, 2002, regarding common standards in the telecommunication industry), lobbying for excise tax hikes does not seem to be observed explicitly. (A recent exception is the call for a carbon tax made by major oil companies, which might be partly motivated by profit gains. $)^{13}$ The analysis of this paper suggests that there are reasons to expect it to be a concealed objective for fringe domestic firms.

\footnotetext{
13 "In actively pushing for a carbon tax behind the scenes, Exxon becomes the first major American energy company to move closer to the positions of European energy firms... which [in 2015] have publicly advocated for a price on carbon." http://www.wsj.com/articles/exxon-touts-carbon-tax-to-oil-industry-1467279004. Seade (1985: 23) provides an early example of oil companies benefitting from a common cost increase (the rise in the crude oil price in 1973-74).
} 


\section{References}

Acheson, K. (1977). 'Revenue vs protection: the pricing of wine by the Liquor Control Board of Ontario'. Canadian Journal of Economics, 10: 246-262.

Adachi, T. and Ebina, T. (2014). 'Double marginalization and cost pass-through: Weyl-Fabinger and Cowan meet Spengles and Bresnahan-Reiss', Economic Letters, 122: 170-175.

Amir, R., Halmenschlager, C. and Knauff, M. (2016). 'Does the cost paradox preclude technological progress under imperfect competition?', Journal of Public Economic Theory, DOI: 10.1111/jpet.12199.

Anderson, S.P. , de Palma, A. and Kreider, B. (2001). 'Tax incidence in differentiated product oligopoly', Journal of Public Economics, 81: 173-182.

Anderson, K. (2010). 'Excise and import taxes on wine versus beer and spirit: An international comparison'. Economic Papers, 29: 215-228.

Baker, P. and Brechling, V. (1992). 'The impact of excise duty changes on retail prices in the UK'. Fiscal Studies, 13: 48-65.

Bergman, M. U. and Hansen, N.L. (2013). 'Are excise taxes on beverages fully passed through to prices? The Danish evidence'. University of Copenhagen WP.

Besley, T.J. and Rosen, H.S. (1998). 'Vertical externalities in tax setting: Evidence from gasoline and cigarettes'. Journal of Public Economics, 70: 383-98.

Besley, T.J. and Rosen, H.S. (1999). 'Sales taxes and prices: an empirical analysis', National Tax Journal, 52: $157-78$

Bhagwati, J.N., Panagariya, A. and Srinivasan, T.N. (1998). Lectures on international trade. Cambdrige, Mass.: MIT Press.

Bird, R.M. and Wallace, S. (2010). 'Taxing alcohol in Africa: reflections and updates'. Int. St. Pr. WP 10-31.

Blake, D. and Nied, A. (1997). 'The demand for alcohol in the United Kingdom'. Applied Economics, 29: $1655-1672$.

Bonnet, C. and Réquillart, V. (2013). 'Tax incidence with strategic firms in the soft drink market'. Journal of Public Economics, 106: 77-88.

Brander, J. A. and Spencer, B. J. (1984). 'Tariff protection and imperfect competition', in H. Kierzkowski (ed.) Monopolistic competition and product differentiation and international trade. New York: Oxford Economic Press, 194-206.

Bryson, A. (2004). 'Unions and workplace closure in Britain, 1990-1998'. British Journal of Industrial Relations. 42: 283-302.

Calmfors, L. (1982). 'Employment policies, wage formation and trade union behaviour in a small open economy'. Scandinavian Journal of Economics. 84: 345-373.

Cnossen, S. (ed.) (2005). Theory and practice of excise taxation: Smoking, drinking, gambling, polluting and driving. Oxford: Oxford University Press.

Cnossen, S. (2006). 'Tobacco taxation in the European Union'. Finanzarchiv, 62: 305-322. 
Cnossen, S. (2007). 'Alcohol taxation and regulation in the European Union'. International Tax and Public Finance, 699-732.

Collie, D.R. (2006). 'Tariffs and subsidies under asymmetric oligopoly: Ad valorem versus specific instruments'. Manchester School, 74: 314-33.

Crawford, I., Smith, Z. and Tanner, S. (1999). 'Alcohol taxes, tax revenue and the Single European market'. Fiscal Studies, 20: 287-304.

Delipalla, S. and Keen, M.J. (1992). 'The comparison between ad valorem and specific taxation under imperfect competition'. Journal of Public Economics, 49: 351-367.

Delipalla, S. and O'Donnel O. (2001). 'Estimating tax incidence, market power and market conduct: The European cigarette industry'. International Journal of Industrial Organization, 19: 885-908.

Dixit, A. (1987). 'Issues of strategic trade policy for small countries'. Scandinavian Journal of Economics, 89: 349-367.

Dumont, M., Rayp, G. and Willemé, P. (2006). 'Does internazionalization affect union bargaining power? An empirical study for five EU countries'. Oxford Economic Papers, 58: 77-102.

European Commission (2004). 'Report to the Council on the rates of excise duty applied on alcohol and alcoholic beverages', http://europa.eu.int/comm/taxation_customs/com_2004_223 en.pdf

Esteller-Moré, A., Galmarini, U. and Rizzo, L. (2012). 'Vertical tax competition and consumption externalities in a federation with lobbying'. Journal of Public Economics, 96: 295-305.

Février, P. and Linnemer, L. (2004). 'Idiosyncratic shocks in an asymmetric Cournot oligopoly'. International Journal of Industrial Organization, 22: 835-848.

Fullerton, D. and Metcalf, G.E. (2002). 'Tax incidence'. NBER WP n. 8829.

Gallet, C.A. (2007). 'The demand for alcohol: A meta-analysis of elasticities'. Australian Journal of Agricultural and Resource Economics, 51: 121-135.

Gallus, S., Schiaffino, A., La Vecchia, C., Townsend, J. and Fernandez, E. (2006). 'Price and cigarette consumption in Europe'. Tobacco Control, 15: 114-119.

Grossman, G.M. and Helpman, E. (2002). Interest groups and trade policy. Princeton: PUP.

Häckner, J. and Herzing, M. (2016). 'Welfare effects of taxation in oligopolistic markets', Journal of Economic Theory, 163: 141-166.

Katrak, H. (1977). 'Multi-national monopolies and commercial policies'. Oxford Economic Papers, 29: 28391.

Kay, J.A. and Keen, M. (1987). 'Alcohol and tobacco taxes: criteria for harmonisation'. In Cnossen, S. (ed), Tax coordination in the European Community. Deventer: Kluwer, chapter 3: 85-111.

Keen, M. and Lahiri, S. (1993). 'Domestic tax reform and international oligopoly'. Journal of Public Economics, 51: 55-74.

Keen, M., Lahiri, S. and Raimondos-Møller, P. (2002). 'Tax principles and tax harmonization under 
imperfect competition: A cautionary example'. European Economic Review, 46: 1559-1568.

Keen, M. and Ligthart, J.E. (2005). 'Coordinating tariff reduction and domestic tax reform under imperfect competition'. Review of International Economics, 13: 385-390.

Kimmel, S. (1992). 'Effects of cost changes on oligopolists' profits'. Journal of Industrial Economics, 40: 441-449.

Lahiri S. and Ono, Y. (1997). 'Asymmetric oligopoly, international trade and welfare: A synthesis'. Journal of Economics, 65: 291-310.

Lockwood, B. and Migali, G. (2009). 'Did the single market cause competition in excise taxes? Evidence from EU countries’. Economic Journal, 119: 406-429.

Manning W.G., Blumberg L., Moulton L.H. (1995). 'The demand for alcohol - the differential response to price'. Journal of Health Economics, 14: 123-48.

Mason, R. (2002). 'Cost-raising strategies in a symmetric, dynamic duopoly'. Journal of Industrial Economics, 50: 317-335.

Matschke, X. (2010). 'Do labor market imperfections increase trade protection? A theoretical investigation'. B.E. Journal of Economic Analysis \& Policy, 10: Iss.1 (Topics), Article 50.

Matschke, X. and Sherlund, S. (2006). 'Do labor issues matter in the determinants of U.S. trade policy? An empirical reevaluation. American Economic Review, 96: 405-421.

Meng, Y., Brennan, A., Purshouse, R., Hill-McManus, D., Angus, C., Holmes, J., and Meier, P.S. (2014). 'Estimation of own and cross price elasticities of alcohol demand in the UK: A pseudo-panel approach using the Living Costs and Food Survey 2001-2009'. Journal of Health Economics, 34: 96-103.

Neary, P.J. (2010). 'Two and a half theories of trade'. World Economy, 33: 1-19.

Norström, T. (2005). 'The price elasticity for alcohol in Sweden 1984-2003'. Nordisk Alkohol \& Narkotikatidskrift, English supplement, 22: 87-101.

Palokangas, T. (2003). 'The political economy of collective bargaining'. Labour Economics, 10: 253-264.

Rama, M. and Tabellini, G. (1998). 'Lobbying by capital and labor over trade and labor market policies'. European Economic Review, 42: 1295-1316.

Reny, P.J., Wilkie, S.J. and Williams, M.A. (2012). 'Tax incidence under imperfect competition: Comment', International Journal of Industrial Organization, 30: 399-402.

Santoni, M. (1996). 'Union-oligopoly sequential bargaining: trade and industrial policies'. Oxford Economic Papers, 48: 640-663.

Seade, J. (1985). 'Profitable cost increases and the shifting of taxation'. DP No. 260, University of Warwick.

Weyl, G.E. and Fabinger, M. (2013). 'Pass-through as an economic tool: Principles of incidence under imperfect competition'. Journal of Political Economy, 121: 528-583.

Young, D.J. and Bielinska-Kwapisz, A. (2002). 'Alcohol taxes and beverage prices'. National Tax Journal, 55: 57-73. 


\section{Appendices}

\section{Appendix A.}

Proof of Proposition 1. Totally differentiating Eq. (1), by using Cramer's rule and recalling that $\psi$ and P are seen as exogenous in partial equilibrium, the comparative statics of the excise duty is as follows ${ }^{14}$

$$
\begin{aligned}
& \frac{d X^{h}}{d s}=\left[\frac{\psi X^{h} 2 /(2-z)}{D\left(X^{h}+X^{*}\right)^{3} w^{*}}\right]\left[-3 w^{*}+\theta P\right] \geq 0 \text { for } \theta P \geq 3 w^{*} ;<0 \text { otherwise } \\
& \frac{d X^{*}}{d s}=\left[\frac{\psi X^{h} 2 /(2-z)}{D\left(X^{h}+X^{*}\right)^{3}(2-z) w^{*}}\right]\left[[2-3 z] w^{*}-(6-z) \theta P\right] \leq 0 \text { for } \theta P \geq\left[\frac{2-3 z}{6-z}\right] w^{*}
\end{aligned}
$$

$\frac{d\left(X^{h}+X^{*}\right)}{d s}=-\left[\frac{4 \psi /(2-z)}{D\left(X^{h}+X^{*}\right)^{2}}\right]<0$

$\frac{d p}{d s}=\left[2+\partial w^{h} / \partial s\right] \equiv 4 /(2-z)>1$

$\frac{d A^{h}}{d s}=\left(\theta P-w^{*}\right)\left(\frac{A^{h}}{\Gamma w^{*}}\right) \geq 0$ for $\theta P \geq w^{*},<0$ otherwise

$\frac{d \Pi^{h} / P}{d s}=\left(\theta P-w^{*}\right)\left(\frac{2 \Pi^{h} / P}{\Gamma w^{*}}\right) \geq 0$ for $\theta P \geq w^{*},<0$ otherwise

where $\mathrm{D}=\left[\psi /\left(\mathrm{X}^{\mathrm{h}}+\mathrm{X}^{*}\right)^{2}\right]^{2}>0 ; \quad \mathrm{A}=[\mathrm{z} /(2-\mathrm{z})](\Gamma / \mathrm{P}) \mathrm{X}^{\mathrm{h}} \quad$ is the typical union's indirect utility and $\Pi^{\mathrm{h}} / \mathrm{P}=\left[\left(\mathrm{w}^{*}+\mathrm{s}\right) / \mathrm{P}\right] \mathrm{X}$ is the typical home firm's indirect profit function, with $\Gamma \equiv \theta \mathrm{P}+\left(\mathrm{w}^{*}+2 \mathrm{~s}\right) ; \mathrm{X}^{\mathrm{h}}$ is given by Eq. (3.2); moreover, from Eq. (2): $\partial \mathrm{w} / \partial \mathrm{s}=2 \mathrm{z} /(2-\mathrm{z})>0$. All the expressions are evaluated at $\mathrm{s}=0$. It is sufficient that the foreign firm is larger, or $\theta \mathrm{P}>(1-\mathrm{z}) \mathrm{w}^{*}$ for (a.2) to be negatively signed. From Eq. (a.4), note that tax-overshifting is increasing in the union bargaining power parameter $\mathrm{z}$.

\footnotetext{
${ }^{14}$ The systematic derivation leading to Eq.s (a.1)-(a.3) is presented in a further Appendix D, available from the author on request.
} 


\section{Appendix B. General equilibrium effects of the excise tax}

Differentiating the system of Eq.s (3)- (4), the price index P, the optimal consumption demands for the two sectoral goods and the output level in the export sector with respect to the excise tax, and evaluating the result in the neighbourhood of the no-government equilibrium $\mathrm{s}=0$, yields:

$$
\begin{aligned}
& \frac{d \ln n}{d s}=-\left\{\frac{2(\theta P)^{2}(1-\beta)+\left(w^{*} / 2\right)\left[\theta P(1-\beta)(2+z)-w^{*}(2-z)\right]}{p^{I}\left[\theta P+z w^{*} / 2\right]\left[\theta P(1-\beta)+w^{*}\right]}\right\} \geq 0 \text { or }<0 \\
& \frac{d \ln q^{*}}{d s}=-\frac{\left\{\theta P\left[\theta P(1-\beta)-w^{*}(1+\beta)\right]+w^{*}\left(\theta P-w^{*}\right)\right\}}{p^{I}\left(\theta P+z w^{*} / 2\right)\left[\theta P(1-\beta)+w^{*}\right]} \geq 0 \text { or }<0
\end{aligned}
$$

$\frac{d \ln X^{E}}{d s}=-\frac{\alpha \beta}{1-\alpha} \frac{d \ln p^{I}}{d s}<0$

$\frac{d \ln \Omega}{d s}=\left[\frac{d \ln X^{E}}{d s}-\left(\frac{\beta n}{1-\beta(1-n)}\right) \frac{d \ln n}{d s}\right] \geq 0$ or $<0$

$\frac{d \ln c^{I}}{d s}=\frac{d \ln \Omega}{d s}-\frac{d \ln p^{I}}{d s} \geq 0$ or $<0$

$\frac{d \ln c^{E}}{d s}=\frac{d \ln \Omega}{d s} \geq 0$ or $<0$

$\frac{d \ln X^{I}}{d s}=\frac{d \ln c^{I}}{d s}+\frac{d \ln (1-n)}{d s} \geq 0$ or $<0$

$\frac{d \ln X^{*}}{d s}=\frac{d \ln c^{I}}{d s}+\frac{d \ln n}{d s} \geq 0$ or $<0$

$\frac{d \ln p^{I}}{d s}=\frac{2}{\theta P(1-\beta)+w^{*}}>0$ 


$$
\begin{aligned}
M C \equiv & \left(1+\frac{\beta}{1-\alpha}\right) \frac{d \ln p^{I}}{d s}+\frac{\beta n}{1-\beta(1-n)} \frac{d \ln n}{d s}= \\
& \left\{\begin{array}{l}
{\left[2(1-\alpha+\beta)(1-\beta) p^{I}(\theta P+z w * / 2)\right]+} \\
{[\beta n / 2(2-z)]\left[\left(w^{*}\right)^{2}\left[4 z(1-\alpha+\beta)+(1-a)(2-z)^{2}\right]+\right.} \\
+[\beta n / 2(2-z)] \theta P\left[\begin{array}{l}
4 \theta P(2 \beta(2-\alpha)+z(1-\beta)(1-\alpha)) \\
+w^{*}(2+z)(2(1+\beta)(1-\alpha)+4 \beta+z(1-\alpha)(1-\beta)
\end{array}\right]
\end{array}\right. \\
& \left\{\frac{1}{(1-\alpha)[1-\beta(1-n)] p^{I}\left(\theta P+z w^{* / 2}\right)\left[\theta P(1-\beta)+w^{*}\right]}\right\}>0
\end{aligned}
$$

In general equilibrium, the comparative static effects include the effects of the tax on $\mathrm{P}$ and $\Omega$. A sufficient condition for the excise tax to reduce the marginal propensity to import $\mathrm{n}$ (see Eq. b.1) is $\theta \mathrm{P}(1-\beta) \geq \mathrm{W}^{*}(2-$ $\mathrm{z}) /(2+\mathrm{z})$. The larger is the gap between the home and the foreign reservation wage, the higher is foreign penetration and the bigger is the reduction in the marginal propensity to import provoked by the duty. For example, in the absence of unions (i.e. $z=0$ ) and if the two sectors have equal size (i.e. $\beta=1 / 2$ ), the sufficient condition becomes $\theta \mathrm{P} \geq 2 \mathrm{w}^{*}$, i.e. the home firm must be sufficiently smaller than the foreign firm. The necessary and sufficient condition for an increase in the marginal propensity to import is $w^{*}>\theta P(1-\beta)\left\{\frac{(2+z)+\sqrt{(2+z)^{2}+16(2-z) /(1-\beta)}}{2(2-z)}\right\}$. For example, in the absence of unions (i.e. $\left.\mathrm{z}=0\right)$ and if the two sectors have equal size (i.e. $\beta=1 / 2$ ), the condition becomes $\mathrm{w}^{*}>(1.28) \theta \mathrm{P}$, i.e. the foreign firm must be sufficiently smaller than the home firm. Note that a sufficient condition for the excise tax to reduce the typical foreign firm's market share in general equilibrium is $\theta \mathrm{P}(1-\beta) \geq \mathrm{w}^{*}(1+\beta)$ (see Eq. b.2).

\section{General equilibrium effects of union power on the consumer price index}

Using Eq. (3.1) in the main text and the fact that $\mathrm{P}=\left(\mathrm{p}^{\mathrm{I}}\right)^{\beta}$, it follows that, in the neighbourhood of the freetrade equilibrium with $\mathrm{s}=0$ :

$$
\frac{d \ln P}{d z}=\left(\frac{\beta}{2-z}\right)\left(\frac{\theta P+w^{*}}{\theta P(1-\beta)+w^{*}}\right)>0
$$




\section{Proof of Proposition 3.}

Using Eq.s (b.1) to (b.10), the expression in curly bracket of Eq. (11) can be written as:

$$
\begin{aligned}
& \left(\frac{p^{I}-s}{P}-\theta\right)\left(1-q^{*}\right) c^{I}\left\{\left[\frac{d \ln \left(\left(p^{I}-s\right) / P-\theta\right)}{d s}+\frac{d \ln \left(1-q^{*}\right)}{d s}+\frac{\mathrm{d} \ln c^{I}}{d s}\right]\right\} \equiv \\
& \equiv\left(\frac{p^{I}}{P}-\theta\right)\left(1-q^{*}\right) c^{I}
\end{aligned}
$$

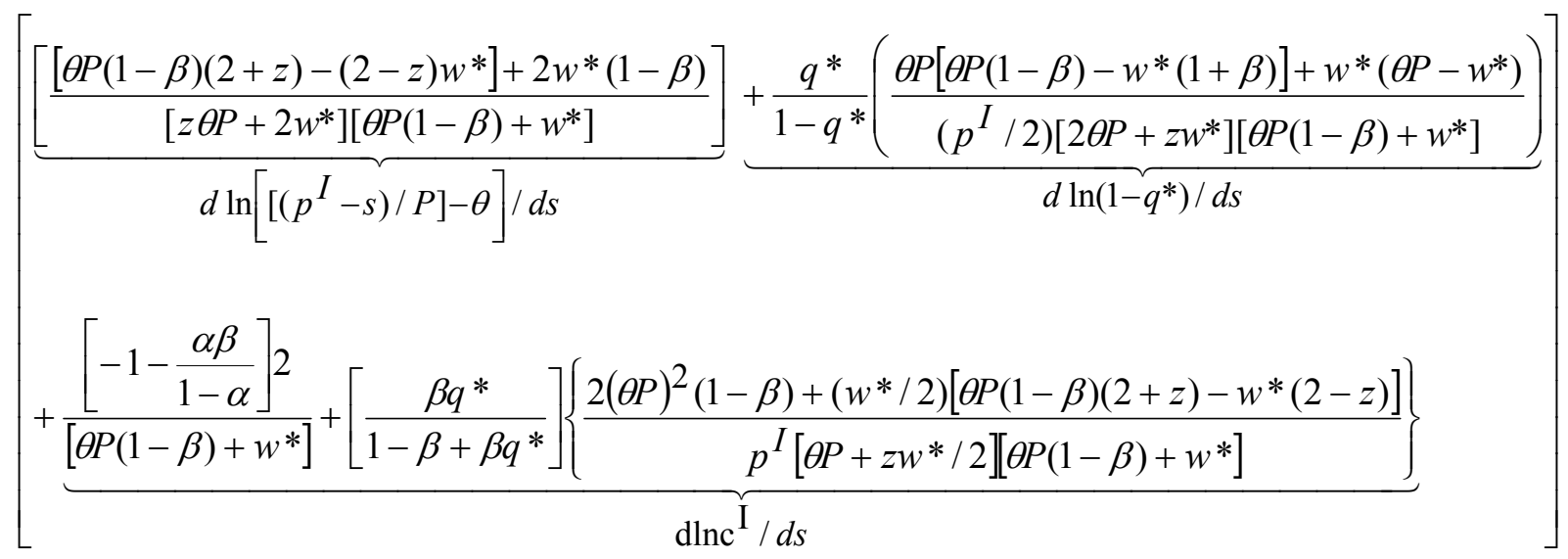

$$
\begin{aligned}
& \equiv\left(\frac{p^{I}}{P}-\theta\right)\left(1-q^{*}\right) c^{I} \frac{d \log p^{I}}{d s} \\
& {\left[\begin{array}{l}
{\left[\frac{\left[\theta P(1-\beta)(2+z)-(2-z) w^{*}\right]+2 w^{*}(1-\beta)}{2\left[z \theta P+2 w^{*}\right]}\right]+\left(\frac{\theta P\left[\theta P(1-\beta)-w^{*}(1+\beta)\right]+w^{*}\left(\theta P-w^{*}\right)}{2 w^{*}\left[\theta P+w^{*}\right]}\right)} \\
+\left[-1-\frac{\alpha \beta}{1-\alpha}\right]+\left[\frac{\beta}{1-\beta+\beta q^{*}}\right]
\end{array}\left\{\begin{array}{l}
\left\{\frac{(\theta P)^{2}(1-\beta)+\left(w^{*} / 4\right)\left[\theta P(1-\beta)(2+z)-w^{*}(2-z)\right]}{\left[\theta P+w^{*}\right]^{2}}\right\}
\end{array}\right]\right.}
\end{aligned}
$$

In Eq. (b.12), the expressions from the second line onwards are evaluated in the neighbourhood of $\mathrm{s}=0$. From Eq.s (b.1) and (b.2), the foreign firm must be sufficiently larger than the home firm for the first, second and forth term in the square bracket of Eq. (b12) to be positive, namely $\theta \mathrm{P} \geq \max \left\{\mathrm{w}^{*}(1+\beta) /(1-\beta)\right.$, $\mathrm{W}^{*}(2-$ $\mathrm{z}) /[(2+\mathrm{z})(1-\beta)]\}$, whereas the third term is negative. Thus, a sufficient condition for Eq. (b.12) to take on a positive sign is that the sum of the second and third term is non-negative. Solving the corresponding secondorder inequality in $\theta \mathrm{P}$, a sufficient condition for $\mathrm{b} 12)>0$ is $\theta \mathrm{P} \geq \mathrm{w}^{*} \mathrm{~K}_{2}$, where 


$$
K_{2} \equiv \max \left\{K_{0} \equiv \frac{(2-z)}{(2+z)(1-\beta)} ; \mathrm{K}_{1} \equiv\left[\frac{2+\beta+\frac{2 \alpha}{1-\alpha}+\sqrt{\left(2+\beta+\frac{2 \alpha}{1-\alpha}\right)^{2}+4(1-\beta)\left[3+\frac{2 \alpha \beta}{1-\alpha}\right]}}{2(1-\beta)}\right]\right\}
$$

Table 1 the main text reports numerical examples for $K_{1}$. Note that, for $\alpha \geq 0.4, K_{1}>K_{0}$.

\section{Appendix C}

\section{Derivation of Eq.s (9) and (10) in the main text.}

Considering condition iii) for each lobby, the tax policy maximises the sum of the government's and that lobby's welfare, given the other lobby's contribution and Eq. (7) yields:

$\left\{\mathrm{d}\left[\Pi^{\mathrm{I}}\left(\mathrm{s}^{\circ} ;.\right) / \mathrm{P}\right] / \mathrm{ds}-\mathrm{dME}\left(\mathrm{s}^{\circ}\right) / \mathrm{ds}\right\}+\left\{\mathrm{dME}\left(\mathrm{s}^{\circ}\right) / \mathrm{ds}+\mathrm{dMU}\left(\mathrm{s}^{\circ}\right) / \mathrm{ds}+\mathrm{d}\left[\mathrm{R}\left(\mathrm{s}^{\circ}\right) / \mathrm{P}\right] / \mathrm{ds}\right\}=0$

$\left\{\mathrm{d}\left[\mathrm{A}^{\mathrm{I}}\left(\mathrm{s}^{\circ} ;.\right)\right] / \mathrm{ds}-\mathrm{dMU}\left(\mathrm{s}^{\circ}\right) / \mathrm{ds}\right\}+\left\{\mathrm{dME}\left(\mathrm{s}^{\circ}\right) / \mathrm{ds}+\mathrm{dMU}\left(\mathrm{s}^{\circ}\right) / \mathrm{ds}+\mathrm{d}\left[\mathrm{R}\left(\mathrm{s}^{\circ}\right) / \mathrm{P}\right] / \mathrm{ds}\right\}=0$.

From condition ii) the optimal tax policy $\mathrm{s}^{\circ}$ maximises the government objective function, given the contributions of the two lobbies and Eq. (8), yields:

$\mathrm{dME}\left(\mathrm{s}^{\circ}\right) / \mathrm{ds}+\mathrm{dMU}\left(\mathrm{s}^{\circ}\right) / \mathrm{ds}+\mathrm{d}\left[\mathrm{R}\left(\mathrm{s}^{\circ}\right) / \mathrm{P}\right] / \mathrm{ds}=0$.

Using Eq. (c1) and (c2) together gives Eq. (9). From condition ii) and Eq. (8) yields:

$\mathrm{dME}\left(\mathrm{s}^{\circ}\right) / \mathrm{ds}+\mathrm{dMU}\left(\mathrm{s}^{\circ}\right) / \mathrm{ds}+\mathrm{d}\left[\mathrm{R}\left(\mathrm{s}^{\circ}\right) / \mathrm{P}\right] / \mathrm{ds}=0$.

However, if the contribution schedules are locally truthful, meaning here that:

$\mathrm{ME}=\max \left[0,\left(\Pi^{\mathrm{I}}(\mathrm{s} ;.) / \mathrm{P}-\Pi^{\prime} / \mathrm{P}\right)\right]$,

$\mathrm{MU}=\max \left[0, \mathrm{~A}^{\mathrm{I}}(\mathrm{s})-\mathrm{A}^{\prime}\right]$,

where $\Pi$ '/P and $A^{\prime}$ are the welfare levels each lobby would get by paying no contributions when the government chooses its policy as a best response to the other lobby's contribution, it follows that $\mathrm{dME}\left(\mathrm{s}^{\circ}\right) / \mathrm{ds}+\mathrm{dMU}\left(\mathrm{s}^{\circ}\right) / \mathrm{ds}=\mathrm{d}\left[\Pi^{\mathrm{I}}\left(\mathrm{s}^{\circ} ;.\right) / \mathrm{P}\right] / \mathrm{ds}+\mathrm{d}\left[\mathrm{A}^{\mathrm{I}}\left(\mathrm{s}^{\circ} ;.\right) / \mathrm{P}\right] / \mathrm{ds}$.

This gives Eq. (10) in the main text. 